\title{
A lelkiismeret alkotmányossága
}

\section{DELI GERGELY ${ }^{1}$}

A tanulmány alapkérdése, hogy egy keresztény ember milyen alapon perelhet. Még ha saját, alkotmányban védett alapjogáról van szó, nem lenne helyesebb, ha szeliden lemondana igényéröl? A tanulmány az esti lelkiismeret-vizsgálat eszközeivel keres választ erre a kérdésre. Az uralkodó, emberi méltóságra alapozott, individuális, következményorientált, emberi jogokban megnyilvánuló és „racionális” alkotmányosság helyett felvázolja egy „érzelmi” alkotmányosság alapvonalait, amely az emberi üdvösségre alapoz, személyes, szándékorientált, és tárgyául a bünöket teszi meg.

Kulcsszavak: lelkiismeret, mainstream alkotmányosság, keresztény alkotmányosság, alapjogok

\section{The Constitutional Dimension of Conscience}

The basic question of the study is on what grounds a Christian can sue? Even if it were his/her fundamental rights protected by the Constitution, would it be better, if he/she mildly gave up his/her claim? This essay seeks to address this problem with the help of the evening examination of conscience. It draws the contours of an "emotional", intent-oriented constitutionalism, based on human salvation and focusing on vices, instead of the mainstream, individualistic, consequence-oriented and rational constitutionalism.

Keywords: conscience, mainstream constitutionalism, Christian constitutionalism, fundamental rights

\section{Miről lesz szó?}

Sohasem értettem, hogy egy keresztény ember milyen alapon perelhet. Még akkor is, ha saját, alkotmányban védett alapjogáról van szó, nem lenne helyesebb, ha szelíden lemondana igényéről? Rudolf von Jhering zengzetes felhívásában a jogunkért és ezzel egyben a jogért való küzdelemre ${ }^{2}$ értem és érzem a heroizmust, de ez önmagában számomra nem nyújt kielégítő választ a fenti

1 Egyetemi tanár, Széchenyi Egyetem, Deák Ferenc ÁJK; e-mail: gdeli@mcc.hu.

2 Rudolf von Jhering: Kampf ums Recht. Bécs, Manz, 1894. 16. 
dilemmára. Ezért a jelen tanulmányban megpróbálok saját választ megfogalmazni, és az esti lelkiismeret-vizsgálat eszközeivel elemzek alkotmányjogi problémákat. Ez elsőre talán furcsának, egyesek számára akár ijesztőnek tűnhet, annak ellenére, hogy mind az esti időszak alkotómunkára történő kihasználása, mind a lelkiismeretvizsgálat az európai kultúra szerves része. Az előbbi kapcsán elég, ha Aulus Gelliusra ${ }^{3}$ vagy Berzsenyi Dánielre gondolunk:

Lefestem szüretem estvéli óráit, Ha már cselédimet nyugodni eresztem, És csak alig hallom a vígság lármáit, Agg diófám alatt tüzemet gerjesztem.

Leplembe burkolva könyökemre dủlök, Kanócom pislogó lángjait szemlélem, A képzelet égi álmába merủlök, S egy szebb lelki világ szent óráit élem. ${ }^{4}$

A lelkiismeret-vizsgálat esetében hirtelen Seneca ${ }^{5}$ és Loyolai Szent Ignác ${ }^{6}$ juthat eszünkbe. Ami a többit illeti, amióta alkotmány van, léteznek alkotmányjogi problémák is, és ezek sine dubio felfoghatók tudományos problémákként is. Ami tehát a figyelmét máris nekünk ajándékozó olvasó (lectori salutem!) kényelmetlenségét okozhatja, az két dolog: az esti lelkiismeret-vizsgálat és az alkotmányjogi problémák összekapcsolása egy önmagát tudományosnak minősítő gyűjteményes kötet keretében. Ez pedig kényes kérdés, hiszen a szerző vagy megvédi megközelítése tudományosságát, vagy visszaél a szerkesztők jóindulatával. Azonban nyugodt lelkiismerettel biztosíthatok mindenkit, hogy szándékaim tisztességesek és egyben tudományosak is.

A lelkiismeret-vizsgálat ugyanis tulajdonképpen nem egyéb, mint az önnön magányban véghezvitt fogalmi elemzés. Az ember bizonyos konkrét élettörténéseket, cselekményeket meghatározott fogalmak alá (jelesül a bünök és erények fogalmai alá) próbál szubszumálni, kategóriákat állít fel, distinkciókat tesz és mérlegel. Azaz csupa olyan gondolati műveletet végez, amelyek megfelelhetnek a tudományos módszerek szigorú elvárásainak is. A lelkiismeret-vizsgálat kétségkívül rendkívül személyes tevékenység, de módszere, a fogalmi analízis egybeeshet a tudományos módszerrel. Kezdeti, hirtelen és talán elkapkodott idegenkedésünket végeredményben az okozhatta, hogy valóban nagyon kevés olyan dolog létezik, amely egyszerre személyes és tudományos is. A helyes lelkiismeret-vizsgálat azonban akár felfogható ilyennek is, talán azért, mert per naturam törekszik egyfajta objektivitásra és univerzalitásra.

3 Aulus Gellius: Attikai éjszakák. Budapest, Európa, 1968. 1, 4.

4 Berzsenyi Dániel: Levéltöredék barátnémhoz (részlet).

5 Lucius A. Seneca: De ira. A haragról. Budapest, General, 2001. 3, 36, 1-4.

6 Loyolai Szent Ignác: Lelkigyakorlatok. Budapest, Jezsuita, 2019. 5, 1. 
Miután megnyugodtunk a jelen tanulmány tárgyának (alkotmányjogi problémák) és módszerének (lelkiismeret-vizsgálat mint fogalmi analízis) tudományosságát illetően, lássuk röviden, miről nem lesz szó. Nem lesz szó mindenekelőtt a vonatkozó szakirodalomban vallási konstitucionalizmusnak (religious constitutionalism) ${ }^{7}$ nevezett irányzatról. Ez a II. világháborút követő ideológiai űrben az Európában megerősödő és évtizedekre vezető szerepre jutó szociáldemokrata pártok által felkarolt irányzat, amely az alapjogok végső alapjául az ember egyenlő és elidegeníthetetlen emberi méltóságát állította. Közkeletű tévedés, hogy az emberi méltóság ezen kitüntetett szerepe a náci rémtettekkel való szembenézés következménye lett volna. A gondolat már jóval a szélsőjobb térnyerése előtt, az 1920-as években megjelent, pápai enciklikákban testet öltött, ${ }^{8}$ és lényegében az volt, hogy a világi befolyását rohamosan elvesztő katolicizmusnak újra ütőképes ideológiai hátteret biztosítson, és a sokfelé az állam által elnyomott vagy éppen üldözött keresztényeknek jogi védelmet nyújtson. ${ }^{9}$ Nem véletlen, hogy később, az 1960-as évek baloldali mozgalmai oly sok energiát szántak a korábban nagymértékben átkatolicizált emberi méltóság fogalmának újrakoncipiálására.

Másrészt nem lesz szó Jézus alkotmánytanáról sem, hiszen nem volt neki, legalábbis nem tudunk róla. Mégis a vizsgálódáshoz szükséges szellemi muníció nagy része az evangéliumokból származik. És nem lesz szó a jézusi alkotmánytan hiányát a középkorban kitöltő skolasztikus, illetve természetjogi alkotmányosságról sem. Ez utóbbiakról már terjedelmes szakirodalom szól, ${ }^{10}$ amelyből igen körültekintően tájékozódhat az érdeklődő. A jelen tanulmánynak az a célja, hogy megmutassa, hogy az alkotmányjogi problémákat nem csak az uralkodó kliséknek megfelelően, a bejáratott tesztekkel és szókészlettel és a (politikailag vagy egyéb szempontból) korrekt ideológiai alapról lehet megvizsgálni. A végső soron mindannyiunkat érintő alkotmányjogi problémákat az erények és a bünök mérlegén is meg lehet mérni. Hogy egyeseket e módszer aggaszt, legyen az ő dolguk. A tudomány dolga, hogy néha aggasszon bennünket.

Szóval miről is lesz végső soron szó? Az uralkodó, emberi méltóságra alapozott, individuális, következményorientált, emberi jogokban megnyilvánuló és „racionális” alkotmányosság helyett egy erőtlen gondolatkísérletről, az „érzelmi” alkotmányosságról, amely az emberi üdvösségre alapoz, személyes, szándékorientált és tárgyául a bünöket teszi meg. Elvárásunk azonban, hogy ez utóbbi, lelkiismereti alkotmányosság legalább potenciálisan képes legyen mindazon funkciók betöltésére, mint az előbbi, mainstream alkotmányosság.

7 Erről l. Perry Dane: Foreword: On Religious Constitutionalism. Rutgers Journal of Law and Religion, 16. (2015), 460.

8 Elsősorban a Divini redemptoris említendő.

9 Ld. Samuel Moyn: Christian Human Rights. Philadelphia, University of Pennsylvania Press, 2015.

10 Pl. ld. Günther Mensching: Moderne Elemente der Staatsauffassung des Thomas von Aquin. In Rolf Schönberger (szerk.): Die Bestimmung des Menschen und die Bedeutung des Staates. Baden-Baden, Nomos, 2017. 227-248. 


\section{Hogy nézzen ki a lelkiismeret alkotmányossága?}

Ha egy közvetlenül evangéliumi ihletettségű alkotmányosságot próbálunk körvonalazni, már a kezdet kezdetén komoly nehézségekbe ütközünk. Az egyik, hogy Jézus elég egyértelműen rögzítette, hogy az ő országa nem e világból való. ${ }^{11}$ A másik az, hogy saját tanítását igyekezett a világi autoritásoktól függetleníteni: „Adjátok meg azért a mi a császáré a császárnak; és a mi az Istené, az Istennek."12 Azaz Jézusnak nemcsak, hogy nem volt államelméleti koncepciója, de egyben el is fogadta az államot olyannak, amilyen. Jézus nem egy ideális vagy praktikus állam képét vázolta fel, hanem arra koncentrált, hogy a tanait követők miképp viszonyuljanak a létező államhoz. Jézusnak azonban, mostani nehéz helyzetünket csak fokozandó, nemcsak államelmélete, hanem jogelmélete sem volt. Vagy amennyiben a jogelmélet fogalmát tágan értelmezzük, egyfajta negatív, önmegsemmisítő jogelmélettel operált: „A ki egyik arczodat megüti, fordítsd néki a másikat is; és attól, a ki felső ruhádat elveszi, ne vond meg alsó ruhádat se. Mindennek pedig, a ki tőled kér, adj; és attól, a ki elveszi a tiédet, ne kérd vissza." ${ }^{13}$ Azaz nem jogvédelemmel állunk szemben, hanem joglemondással. És még egyértelműbben: „Ember, ki tett engem köztetek biróvá vagy osztóvá?”" ${ }^{14}$ Jézus nem a jogvitára, annak megoldására fókuszált, hanem a jogvita alanyára. Hogy lesz ezekből, a józan ész szerint értett állam- és jogfogalommal összeegyeztethetetlen elvárásokból egy, a jézusi tanokra alapozott lelkiismereti alkotmányosság?

Az államra vonatkozó két fenti kritériumból (nem lényeges, mivel e világi, és amúgy is el kell fogadni, bármilyen legyen is) a létező államokra nézve azt a következtetést vonhatjuk le, hogy az államra vonatkozó tudomány csupán abban a mértékben értékelhető pozitívan a lelkiismereti alkotmányosság szempontjából, ha polgárát az üdvösségre segíti, de legalábbis nem téríti el attól. Ebben az állításban voltaképpen semmi újdonság nincs. Egyszerủen az arisztotelészi gondolat ${ }^{15}$ ad analogiam újrafogalmazása.

E fenti elvárásból következően az emberi jogokat nem a liberális megközelítésnek megfelelően, az állami önkény korlátjaiként, hanem az üdvösség eszközeiként kell értelmeznünk. De nem követhetjük a kereszténydemokrata nézetet sem, amely az alapvető jogokat mint a kereszténységet, az egyes keresztényt, illetve a keresztény tanítást védő vagy a jogrendbe közvetítő értékekként fogja fel. Ha ehhez az államelméleti kerethez most már a jogelméleti kívánalmakat is hozzávesszük, azt látjuk, hogy az alapjogok és az alkotmányjogi védelem funkciója gyökeresen különbözik a klasszikus felfogástól. Az alkotmányjogi panaszkultúrával szemben abból kell kiindulnunk a lelkiismeret alkotmányossága alapján, hogy minden jogállítás, így az emberi jogok állítása is alapvetően bűnben fogant aktus. Aki magának jogot vindikál, az jheringi értelemben harcol a jogáért, és ezen keresztül a jogrendért, de nem a saját üdvösségével

11 Jn 18,36 .

12 Mt 22,21.

13 Lk 6,29.

14. Lk 12,14.

15 Arisztotelész: Nikomakhoszi etika. Budapest, Európa, 1987. 1095a. 
törődik. Lelki alkotmányosságunknak ebből a bűnös alaphelyzetből kell a jogvita végére az üdvösség felé elmozdulnia. E felfogásban az emberi jogok az emberi üdvösség államilag védett eszközeiként működnek. Észszerüség helyett alapmérceként pedig a megbotránkoztatás foka funkcionál majd.

\section{Az eljárás menete}

Hogy a bűnös jogállításból az egyéni üdvösség irányába eljussunk, egy-egy alkotmányjogi probléma elemzésekor az alábbi eljárási cselekményeket érdemes elvégeznünk. Az eljárás három fó részre oszlik. Az első rész a panaszt vizsgálja, a második a normát (legyen az jogszabály vagy bírói döntés), a harmadikban a kettő összemérésére kerül sor. Az első fő részben, a panasz vizsgálata során, elsőként azt kell megállapítanunk, hogy a felhívott alapjog révén mi az adott helyzetben az a legsúlyosabb bűnös szándék, amely az indítványozót a panaszindítvány benyújtására késztethette. Ezt követően meghatározandó, hogy melyik az a kardinális erény, amelynek érvényesülését a felhívott alapjog az adott helyzetben elő tudja mozdítani. A panasz normatív ereje fordított arányosságban áll az emberek megbotránkoztatása iránti képességével. ${ }^{16}$ Minél nagyobb felháborodást okoz a panaszban foglalt jogállításként megjelenő bủnös szándék, annál gyengébb a panasz normatív ereje. (Lásd az 1. ábrán megrajzolt „P” mint panasz vektort, amely a lanyhaságtól az igazságosság felé mutat. Elég hosszú, ami arra utal, hogy normatív ereje nagy, azaz a cselekmény kevésbé volt megbotránkoztató. $)^{17}$

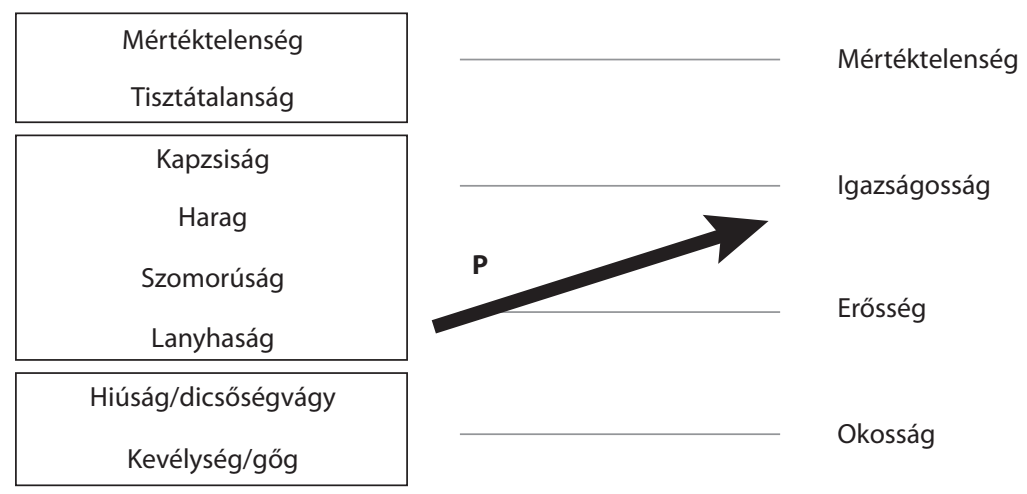

1. ábra: Bünök és erények

Forrás: a szerző szerkesztése

16 A megbotránkoztatás mint szempont Aquinói Szent Tamás tanítására került a modellbe. L. ST, I-II, Q 95, A 2.

17 A vektorok kizárólag szemléltetésre szolgálnak, az itt kifejtetteknek semmilyen matematikai alapjuk nincs. 
A második fő rész első fázisában azt kell felmérni, hogy az ügyben érintett jogszabály a jogalkotói szándék alapján a korábbi helyzethez képest jó, vagy bünös irányba kíván-e elmozdulni. A második lépésben az érintett norma legerényesebb olvasatát kell megkonstruálni az adott tényállás vonatkozásában. A támadott norma (jogszabály vagy bírói döntés) normatív ereje annál nagyobb, minél közelebb áll a feltárt jogalkotói szándék a megállapított ideális olvasathoz. (Lásd a 2. ábrán megrajzolt „N” mint norma vektort. A jogalkotói szándék jó, és a vektor hosszúsága jelzi, hogy nagy az egybeesés a szándék és az optimális olvasat között.)

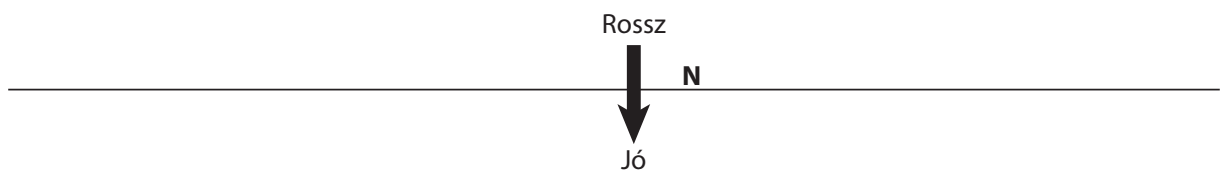

2. ábra: Jogalkotói szándék

Forrás: a szerző szerkesztése

A harmadik fó lépésben a panasz és a norma normatív erejét kell összemérni, és ennek fényében megállapítani a jogkövetkezményt, amely a beavatkozás mértékét tekintve növekvő sorrendben elutasítás, alkotmányos követelmény vagy mulasztás megállapítása, illetve megsemmisítés lehet. (Lásd a 3 ábrát, ahol az előző két vektor, a „P” és a „N" összeadásával megkapjuk a „JK” mint jogkövetkezmény vektort, amely a kívánatos jogkövetkezmény irányába mutat.)

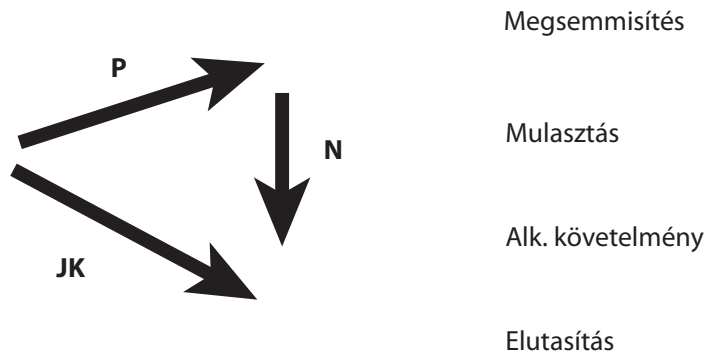

3. ábra: A jogkövetkezmények

Forrás: a szerző szerkesztése

Nézzük most az eljárás egyes lépcsőit kissé részletesebben!

„A minden jogállítás bűn” alaptételéből kiindulva a panaszban testet öltő bűnös szándékokat az ókori egyiptomi szerzetes atyák által meghatározott nyolc vétek ${ }^{18}$ valamelyike alá kell szubszumálnunk. E nyolc vétség az ártalmasság alapján növekvő sor-

18 Johannes Cassianus: Az egyiptomi szerzetesek tanitása. I. rész. Pannonhalma-Tihany, Magyar Bencés Kongregáció, 1998. 134. 
rendbe rendezve a következő: mértéktelenség, tisztátalanság, kapzsiság, harag, szomorúság, jóra való restség, hiúság (dicsőségvágy), kevélység (gőg). ${ }^{19}$ A négy kardinális erény pedig, amelyet az alapjog a maga tiszta formájában védelmezhet: a jól ismert mértékletesség, az igazságosság, az erősség és az okosság. ${ }^{20}$ Érdemes felfigyelnünk arra, hogy a nyolc vétség és a négy erény jól párba állítható egymással. A mértéktelenség és a tisztátalanság legjobb ellenszere a mértékletesség, a kapzsiság és a harag antidotuma az igazságosság, a szomorúságra és a restségre az erősség erényével felelhetünk, végül a hiúság és a gőg ellen az okosság erényével érdemes felruházni magunkat. Annál inkább súlyos szankció alkalmazása indokolt, minél nagyobb a szóban forgó vétség és erény közötti relatív különbség: például a mértéktelenség és az igazságosság között kicsi a távolság, de nagy a gőg és a mértékletesség között. A panasz elemzése során egyrészt a konkrét esetben a panaszosnál szubjektíve felismert vétséget, illetve az alapjog mögött az adott esetben megbúvó, absztrakt erényt kell megállapítanunk. A panasz normatív ereje pedig, mint már említettem, fordított arányban áll a szándék objektíve (azaz társadalmilag) értékelt, megbotránkoztatási képességével.

A második fő lépésben a támadott norma elemzésére kerül sor. A jogalkotói szándékot a fennálló helyzethez képesti elmozdulás függvényében, binárisan (jó/rossz) értékeljük. A norma normatív erejét pedig az határozza meg, hogy miképp viszonyul a norma legjobb erkölcsi olvasatához. Minél inkább közelít a jogalkotói szándék és az optimális olvasat, annál kevésbé leszünk hajlamosak annak megsemmisítésére, és fordítva, minél nagyobb a kettő közötti eltérés, annál inkább súlyos szankcióhoz érdemes nyúlnunk. Például egy gonosz jogalkotás (morally bad law ${ }^{21}$ vagy gesetzliches Unrecht $t^{22}$ ), mondjuk az 1944. évi 1240. ME számú, a zsidók megkülönböztető jelzéséről szóló kormányrendelet esetében a jogalkotói szándék egyértelműen rossz, és ezen annak legjobb erkölcsi olvasata sem sokat segít, normánk gyenge lábakon áll. Ha azonban a jogalkotói szándék pozitív és a norma legjobb olvasatával közel állnak egymáshoz, normánknak biztosabb a helye a jogrendszerben.

A harmadik lépésben a jogkövetkezmény meghatározása történik. Nyilvánvalóan a legkevésbé intruzív szankció az elutasítás, hiszen ebben az esetben a támadott norma érintetlen marad. Ezt követi növekvő erősségben az alkotmányos követelmény meghatározása, a mulasztás megállapítása, végül a legerősebb szankció, a megsemmisítés. Ha mármost a panasz és a norma normatív erejét összevetjük, meghatározhatjuk az optimális jogkövetkezményt. Például ha panaszunk egy súlyosabb vétséget valósít meg, de az érintett alapjog egy kisebb fokú erény, a megbotránkoztató hatás pedig nagy, panaszunk erős lesz. A normánk egy ilyen panasszal szemben csak akkor

19 A hierarchiáról l. Evagriosz Pontikosz: A szerzetes. Pannonhalma, Pannonhalmi Főapátság Bencés Kiadó, 2018. 82.

20 Ld. A katolikus Egyház katekizmusa. Ford. Dr. Pápai Lajos, Dr. Gál Ferenc, Dr. Török József. Budapest, Szent István Társulat, 1994, sub voce „erény”.

21 Ronald Dworkin: Seven Critics. Georgia Law Review, 11. (1977), 1201-1268. 1253. Ehhez 1. Genaro R. Carrio: Professor Dworkin's Views on Legal Positivism. Indiana Law Journal, 55. (1979), 2. 223.

22 Gustav Radbruch: Gesetzliches Unrecht und übergesetzliches Recht. Süddeutsche Juristenzeitung, 1. (1946), 5. 105-108. 107. 
marad talpon, ha a mögötte áló jogalkotói szándék igen pozitív, és a legjobb erkölcsi olvasatához közelít. Nyilvánvalóan ez a séma nemcsak alkotmányjogi esetekben használható fel, hanem mutatis mutandis minden jogvitában.

\section{Konkrét példák}

Az eddigiek meglehetősen elvontan hathatnak, ezért a következőkben a fenti sémát négy igen ismert jogeset példáján szemléltetem. Első esetünk a Riggs v. Palmer. ${ }^{23}$ A történeti tényállás szerint egy idős férfi (Francis B. Palmer) végrendeletében örökösének unokáját, Elmer E. Palmert jelölte ki azzal, hogy az örökséget hagyományokkal terhelte az örökhagyó lányai javára, illetve Elmer Palmernek az édesanyjáról is gondoskodnia kellett. (Az ügy szempontjából kevésbé lényeges elem az, hogy a végrendelet tartalmazott egy olyan kikötést is, hogy ha az örökség akkor nyílna meg, amikor az unoka még kiskorú, az anya eltartása az örökhagyó lányait terhelné, de csak addig, amíg a fiú anyja férjhez nem megy. Az anya később valóban házasságot kötött.) Ezt követően az örökhagyó kifejezte azt a szándékát, hogy meg kívánja változtatni a végrendelet tartalmát. Erről az unoka tudomást szerzett, és hogy ez ne történhessen meg, megölte a nagyapját. Elmer Palmert elítélték gyilkosságért, ezt követően indult el a polgári ügy, amelyben a felperesek az örökhagyó lányai voltak, alperes az örökhagyó gyilkosa és egyben végrendeleti örököse volt.

A központi jogkérdés az volt, hogy megszerezheti-e az örökséget az a személy, aki ennek érdekében megölte az örökhagyót. A bíróság semmissé nyilvánította a végrendeleti rendelkezést, így Palmer végül elesett az örökségtől. A többségi vélemény szerint a végrendelet a „senki sem szerezhet előnyt saját felróható magatartására hivatkozva" elv alapján minősült érvénytelennek. ${ }^{24}$ Azaz a bíróság lényegében morális alapon $^{25}$ eltekintett a tételes jog teljesen egyértelmü rendelkezésétől, és egy általánosan ismert jogelv alapján döntött. A pozitív jog szerint ugyanis annak kell juttatni az örökséget, akit a végrendeletben örökösként jelöltek ki, azonban a bíróság ettől erősebb érvnek tartotta a fenti elvet. ${ }^{26}$

John C. Gray bíró különvéleményt füzött az ítélethez, amelyhez George F. Danforth bíró csatlakozott. Gray bíró véleménye szerint, ha az alkalmazandó törvények egyértelműek és világosak, azokat be kell tartani. A jelen ügyben egyértelmű az a szabály, hogy „azé az örökség, akit a végrendeletben kijelöltek”. Másrészt Gray bíró szerint a többségi álláspont a kétszeres büntetés tilalmát kimondó elvbe ütközik, amely alapján ugyan-

23 Riggs v. Palmer 115 NY 506, 22 NE 188 (1889).

24 A döntés nehézségeiről l. Benjamin N. Cardozo: The Nature of the Judicial Process. Journal of Law: A Periodical Laboratory of Legal Scholarship, 1. (2011), 2. 329-348. 344.

25 Stewart F. Hancock: Meeting the Needs: Fairness, Morality, Creativity and Common Sense. Albany Law Review, 68. (2004), 1. 81-104. 87.

26 Az ügy mögötti jogelméleti nehézségekről l. Rodger Beehler: Legal Positivism, Social Rules, and Riggs v. Palmer. Law and Philosophy, 9. (1990), 3. 285-293. 286. 
azon magatartás miatt senkit nem lehet kétszer büntetni. ${ }^{27}$ Ha ezt összevetjük azzal az elvvel, hogy senki nem hivatkozhat a saját felróható magatartására előnyök szerzése végett, akkor már nemcsak szabályok és elvek versenyeznek egymással, hanem maguk az elvek is konkurálnak. ${ }^{28}$ Hogyan értékelhető ez az eset a modellünkben?

A jogállítást az Elmer-lányok tették, hiszen felperesként ők léptek fel, hogy megszerezzék apjuk vagyonát. A legfőbb vétség, amely hajthatta őket, a kapzsiság volt. A tettük által megvalósítható legfőbb erény pedig az igazságosság lehet, hiszen igazságtalan lenne az, ha apjuk gyilkosa örökölne. Fellépésük maga nem megbotránkoztató, hiszen egy rendkívül botrányos cselekményt elkövető személy haszonszerzése ellen léptek fel. Azaz a „panasz” meglehetősen erős, és egy „szinten” álló vétséget és erényt köt össze.

A norma, amelyet keresetükkel támadtak, a végrendelet azon rendelkezése, amely az örökséget az unokának juttatta. E norma jogalkotói (azaz az örökhagyó) szándéka szerint alapvetően pozitív, hiszen a korabeli társadalmi közegben méltányolható, sőt helyeselhető volt, ha valaki vagyonát férfi lemenőjének kívánta juttatni. A konkrét esetben azonban nehéz erkölcsileg helyes magyarázatát adni, hiszen morálisan nehezen védhető az, hogy a rendelkezés az elhunyt vagyonát saját gyilkosának juttatja. A norma normatív ereje tehát csekély. A panasz és a norma erejének összevetéséből nyert eredmény egy súlyos szankció, a megsemmisítés irányába mutat, amely a jelen esetben természetszerűleg nem a norma jogrendszerből történő kivezetését, csupán az adott esetben való alkalmazhatatlanságát, technikai értelemben érvénytelenségét jelenti. (Lásd a 4. ábrát. A panasz vektora horizontális és hosszú. A norma vektora felfelé mutat, és rövid. Összegük megsemmisítést jelez.)

Megsemmisítés

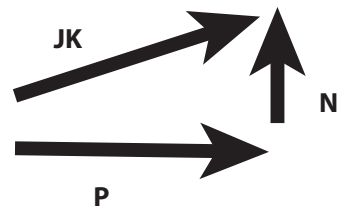

Mulasztás

Alk. követelmény

Elutasítás

4. ábra: A Riggs v. Palmer ügy

Forrás: a szerző szerkesztése

Második esetünk a People v. Collins.${ }^{29}$ A per előzménye meglehetősen triviális. Egy vásárlásból hazafelé tartó hölgy út közben lehajolt, mire valaki a földre lökte. Nem látta,

27 Erről részletesebben 1. William B. Meyer: The Background to Riggs v. Palmer. American Journal of Legal History, 60. (2020), 1. 48-75. 59.

28 Részletesebben 1. Kevin D. Ashley: Teaching Law and Digital Age Legal Practice with an AI and Law Seminar. Chicago-Kent Law Review, 88. (2013), 3. 783-844. 809.

29 People v. Collins 68 Cal2d 319, 438 P2d 33 (1968). 
hogy ki volt az elkövető, és nem hallotta a közeledését sem. Amikor felnézett, észrevette, hogy eltűnt a pénztárcája, és egy sötét ruhába öltözött, copfos szőke nő rohant el mellette. Egy másik szemtanú, aki az utca végén épp a gyepet locsolta, sikoltozásra és arra lett figyelmes, hogy egy sötét ruhás szőke nő sietve beszáll egy sárga autóba, amit egy szakállas fekete férfi vezetett, majd elhajtanak. A jogkérdés az volt, hogy elfogadható-e egy matematikai valószínűségszámításon alapuló bizonyítási eszköz bizonyítékként. ${ }^{30}$ Egy olyan szakértői véleményről volt szó, amely a tényállás egyes elemeinek (szőke nő, szakállas fekete férfi, sárga autó stb.) valószínűségéből kívánta annak valószínűségét megállapítani, hogy az eljárás alá vont pár bünösnek tekinthetö-e, vagy sem. A bíróság válasza nemleges volt.

Az ügyészség érve lényegében az volt, hogy a fenti ismérvek együttes előfordulásának valószínűsége roppant kicsi, emiatt nagyon valószínü, hogy az a pár bűnös, aki ezeket a jegyeket összességükben felmutatja. Ebben a vonatkozásban a bíróság az indokolásban arra hivatkozott, hogy a valószínűségszámításhoz használt számértékek nem feltétlenül reálisak. Nincsenek ugyanis megbízható statisztikai adatok arra vonatkozóan, hogy Los Angeles területén hány darab sárga kocsi található, hány szőke nő van, stb. Másrészt nem lehetünk biztosak abban sem, hogy ezek a tényezők függetlenek egymástól, ${ }^{31}$ mert például a szakáll viselése a feketék között felülreprezentált lehet. De lehetséges összefüggés aközött is, hogy valakinek szőke a haja, és copfban hordja. Ha pedig az egyes tényezők nem függetlenek egymástól, akkor nem lehet olyan módon megállapítani az előfordulásuk együttes valószínűségét, mint ahogy azt a szakértő tette. ${ }^{32}$ Másrészt a valószínűség legfeljebb annyit mutat, hogy mennyi az esélye annak, hogy például egy fekete férfi és fehér nő mint pár létezhet, és nem feltétlenül mutat rá és nem is bizonyítja abszolút módon azt, hogy valóban létezik ez a pár. A valószínűségszámítás nem nyújt sziklaszilárd bizonyítékot arra, hogy a cselekményt elkövették, sem arra, hogy azt bizonyítsa, hogy a szóban forgó két személy, Collinsék voltak a bűnösök. ${ }^{33}$ Éppen ellenkezőleg, a modellből az is levezethető, hogy az adott Los Angeles-i régióban akár több ilyen pár is található. (Külön pikantériája az ügynek, hogy 1968-ban a bírósági indokolásban még „negrónak” hívták a feketéket, és lehetséges, hogy az esküdtszéken belül is volt egy vagy több esküdt, aki ellenérzéssel viseltetett a fehér nő - fekete férfi párokkal szemben.)

Miképp értelmezhető ez az eset a modellünk szerint? A jogállítást a fellebbező afroamerikai férfi, Collins tette. Legrosszabb értelemben tette a jóra való restségre ad példát, hiszen egy esetlegesen jogos büntetéstől kívánt fellebbezésével szabadulni.

30 Ld. William Twining: The New Evidence Scholarship. Cardozo Law Review, 13. (1991), 2-3. 295-302. 297.

31 Erről részletesebben ld. Michael Risinger - Jeffrey L. Loop: Three Card Monte, Monty Hall, Modus Operandi and "Offender Profiling": Some Lessons of Modern Cognitive Science for the Law of Evidence. Cardozo Law Review, 24. (2002), 1. 193-286. 272.

32 Bert Black: A Unified Theory of Scientific Evidence. Fordham Law Review, 56. (4). (1988), 597-695. 644.

33 Cindy J. O'Hagan: When Seeing is not Believing: The Case for Eyewitness Expert Testimony. Georgetown Law Journal, 81. (1993), 3. 741-772. 748. 
A vezeklésben rejlő megjavulás lehetőségére mondott tehát nemet. Tette legjobb értelmezésében az igazságosság erényét realizálhatja, hiszen ha nem bűnös, a fellebbezés ennek megállapításában segíthet. A fellebbezés mint cselekmény önmagában nem megbotránkoztató, hiszen mindenkinek joga van élni vele. Így a panasz ereje viszonylag kicsi, az erény és a vétség közötti távolság is mérsékelt.

A támadott norma az alsóbb fokú bíróság ítélete, amely mögött legfőbb bizonyítékként a fent röviden ismertetett statisztikai számítás állt. A bírói szándék alapvetően pozitív, hiszen az általa bűnösnek vélt személy megbüntetésére irányul, ráadásul egy igen erősnek látszó, objektív, matematikai érv alapján. A norma legjobb erkölcsi olvasata azonban teljesen mást mutat. A statisztikai érv nem egyszerűen félrevezető, hanem téves is, így a szándék és a legjobb olvasat közötti eltérés jelentős, a norma ereje csekély. A fentiek alapján újfent a megsemmisítéshez jutunk, azaz a fellebbviteli bíróság helyesen járt el akkor, amikor az elsőfokú bíróság ítéletét megsemmisítette, és az érintett fórumot új eljárásra utasította. (Lásd az 5 . ábrát. A panasz vektora rövid, enyhén felfelé mutat, a norma vektora szintúgy, a végeredmény, a jogkövetkezményvektor így a megsemmisítés felé jelez.)

Megsemmisítés

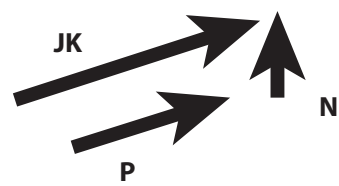

Mulasztás

Alk. követelmény

Elutasítás

5. ábra: A People v. Collins ügy

Forrás: a szerző szerkesztése

Harmadik esetünk a District of Columbia v. Heller. ${ }^{34}$ A District of Columbia egy olyan törvényt alkotott, amelynek célja a fegyvertartás visszaszorítása volt. A törvény rendelkezései alapján az állampolgárok nem tarthattak otthonukban regisztrálatlan kézifegyvert, továbbá felfüggesztették a fegyverek további nyilvántartásba vételét, és a rendőrkapitány sem hosszabbíthatta meg a már létező fegyvertartási engedélyeket. A törvény hatálybalépése után megtagadták Dick A. Heller fegyvertartási engedélyre irányuló kérelmét. Heller - a törvény alkotmányellenességére hivatkozva - megtámadta ezt a határozatot. A jogkérdés az volt, vajon az alkotmány második kiegészítésébe ütközik-e a District of Columbia által hozott törvény. ${ }^{35}$

34 District of Columbia et al. v. Dick Anthony Heller, 128 SCt 2783 (2008).

35 Stephen G. Giles: Mandatory Liability Insurance for Firearm Owners: Design Choices and Second Amendment Limits. Engage, 14. (2013), 1. 18-24. 18. 
Az igenlő, többségi véleményt Antonin G. Scalia bíró fogalmazta meg. Az ítélet indokolása alapján a vitában érintett második alkotmánykiegészítés szövege két részre osztható, és oksági viszony áll fenn közöttük. Ezt figyelembe véve a rendelkezés szövege úgy is megfogalmazható, hogy „mivel egy jól szervezett hadsereg szükséges, ezért nem lehet korlátozni az emberek fegyverviselési jogát". A többségi vélemény szerint az önvédelem joga a ius naturale alapján áll fenn, ${ }^{36}$ és arra a következtetésre jut, hogy az egyéni fegyverviselés miatt a hadsereg hatékonyabb lesz, mert kevesebb időt és anyagi forrást kell a katonák képzésére fordítani. Az ítélet többségi véleménye emellett az egyéni fegyverviselés ,jótékony” hatásait is vizsgálta. Arra a következtetésre jutott, hogy ennek köszönhetően a hadsereg hatékonyabb lesz, ${ }^{37}$ mert kevesebb időt és anyagi forrást kell a katonák képzésére fordítani.

Az ítélet emellett azt állítja, hogy különböző statisztikák bevonásával mindkét oldal képes a saját igaza mellett érvelni. A fegyverviselést támogatók azt idézték fel, hogy személyi sérüléstől mentesen zárul azon esetek $85 \%$-a, ahol a házigazda fegyverrel el tudja riasztani a betörőt. A fegyverviselést ellenzők ezzel szemben olyan adatokra hivatkoznak, amelyek szerint az Egyesült Államokban nagyjából minden ötödik, fiatalkorúak által elszenvedett halál kiváltó oka valamilyen fegyverrel kapcsolatos visszaélés. A fegyverpártiak válasza erre az volt, hogy nem világos a felhozott jelenség mögötti ok-okozati összefüggés, hiszen lehet, hogy ha tilos lenne fegyvert tartani, még több gyilkosság történne, ezért a tilalom kontraproduktív lehet. A tilalmat ugyanis csak a jogkövető állampolgárok tartanák be, a bűnözők a feketepiacon továbbra is fegyverhez jutnának.

A különvélemény azt hangsúlyozza, hogy az alkotmánykiegészítés nem az egyes polgároknak biztosít fegyverviselési jogot, hanem egy potenciális központi elnyomással szemben nyújtott védelmet a szövetségi államok részére. ${ }^{38}$ John P. Stevens bíró szerint az alkotmánykiegészítésben foglalt tiltás címzettje ráadásul a Kongresszus, és nem a szövetségi államok. Stephen Breyer bíró azért kritizálja a többségi véleményt, mert az nem követi az emberélet védelme és a fegyverviselési jog ütközése esetén irányadó precedenst, és nem bizonyítja megfelelően azt, hogy miért tér el ettől a precedenstől. Hogyan értékelhetjük mindezt modellünk szerint?

A jogállítást Heller tette, aki kézifegyvert szeretett volna tartani otthonában. Munkája során amúgy is viselt fegyvert, ezt szerette volna elérni otthonában is. A legfőbb vétek, amelyet ezzel elkövetett, a kevélység: ő, aki a bíróság épületében nyíltan fegyvert viselve teljesít szolgálatot, miért ne tehetné ezt a saját lakásában is? A legfőbb erény, amely az otthoni fegyvertartása mellett szól, az erősség. Bátran megvédi magát és övéit a külső behatolókkal szemben. Az, hogy fegyvert viselne egy alapvetően

36 Robert E. Shapiro: Natural Rights: Requiescant in Pace. Litigation, 39. (2013), 3. 55-58. 58.; David B. Kopel: The Natural Right of Self-Defense: Heller's Lesson for the World. Syracuse Law Review, 59. (2008), 30. 999-1016. 1013.

37 Robert J. Spitzer: Gun Law, Policy, and Politics. New York State Bar Association Journal, 84. (2012), 6. 35-42. 37.

38 Hadley Arkes: The Natural Law Challenge. Harvard Journal of Law \& Public Policy, 36. (2013), 3. 961-975. 965. 
urbánus, sủrủn lakott környéken, eléggé megbotránkoztató, bár ezt moderálja, hogy az Egyesült Államokban rengetegen támogatják az otthoni fegyverviselést. A panasz tehát közepesen erős, és mivel a vétek és az erény nagyjából azonos fajsúlyú, ez is önmagában egy mérsékeltebb szankciót jelez előre.

A jogalkotó szándéka a normával teljesen pozitív volt, hiszen az egyik legfontosabb érték, az emberi élet védelmére irányult. A legjobb erkölcsi olvasata akkor esik ezzel egybe, ha ezt valóban el is éri. Mint láttuk, ebben a ténykérdésben a bíróság sem igen jutott dűlőre. A keresztény intuíció mindenesetre azt súgja, hogy a kevesebb, és nem a több fegyver hozza el a nagyobb békességet, és kevésbé értékes az a „tűzszüneti” állapot, amelyet kölcsönösen a másik fegyverétől való félelem tart fenn. A normánk tehát ebből a szempontból inkább erős, mint gyenge. Mindezt összevetve egy gyenge szankcióhoz, elutasításhoz vagy alkotmányos követelményhez jutunk, épp ellenkező eredményre tehát, mint a jogvitában eljáró bíróság. (Lásd a 6. ábrát. A panasz vektora közepesen hosszú, enyhén felfelé áll, a normáé hosszabb, és lefelé irányul, így összegük egy enyhébb szankcióra mutat.)

Megsemmisítés

Mulasztás

Alk. követelmény

Elutasítás

6. ábra: A District of Columbia v. Heller ügy

Forrás: a szerző szerkesztése

Az utolsó, negyedik eset a Tennessee Valley Authority v. Hill. ${ }^{39}$ Az USA Kongresszusa egy nagyszabású projekt részeként több mérföldes gátrendszert kezdett építeni a Little Tennessee folyón. Az objektum központi eleme a Tellico nevủ völgyzáró gát volt, ami funkciója szerint felduzzasztotta volna az előtte fekvő folyószakaszt. A gátat emellett több százezer lakos energiaellátásának érdekében vízi erőmüként is hasznosították volna, továbbá a projekt számos munkahelyet biztosított volna egy olyan régióban, ahonnan a fiatal munkavállalók folyamatosan elvándoroltak. Az építkezés már javában folyt, amikor 1973-ban hatályba lépett egy, a veszélyeztetett fajokat védő törvény. Ezt követően egy biológus felfedezte, hogy a Little Tennesseeben csigaevő sügérek élnek, és a fajt később fel is vették a veszélyeztetett fajok listájára. Az építkezés ennek ellenére még évekig nem állt le: az illetékes hatóság évről évre megszavazta a szükséges költségvetést annak ellenére, hogy kongresszusi költségvetési vita során

39 Tennessee Valley Authority v. Hiram Hill et al. 437 US 153 (1978). 
is többször felvetették, hogy az építkezés folytatása ellentétes lehet a veszélyeztetett fajokról szóló törvény rendelkezéseivel..$^{40}$

A projekt összköltsége több mint 110 millió dollár volt, amelyből a per kezdetére már körülbelül 57 millió dollárnyi összeget befektettek. ${ }^{41} \mathrm{~A}$ kivitelezéssel megbízott hatóság ezért sem akart leállni az építkezéssel. Erre egy joghallgató, egy jogászprofesszor és egy helyi ügyvéd a veszélyeztetett fajokról szóló törvény megszegése miatt beperelte az állami hatóságot. Az ügy évekig húzódott, és hatalmas sajtóvisszhangot keltett. Az állami hatóság eközben számos alkalommal próbálta a csigaevő sügért egy másik folyóba telepíteni, de nem sikerült bizonyítania annak eredményességét. Biológusok szerint ugyanis tíz-tizenöt év kell ahhoz, hogy biztosan ki lehessen jelenteni azt, hogy egy halfaj áttelepítése sikeres volt-e, vagy sem. Ráadásul a csigaevő sügér egy nagyon kényes édesvízi állatfaj. Az állami hatóságok bosszúságát növelhette az a tény, hogy a környéken évről évre fedeztek fel új sügérfajokat, amelyekből összesen körülbelül 140 nyilvántartott létezik, amelyek csak kismértékben térnek el egymástól.

A jogkérdés az volt, hogy vajon a veszélyeztetett fajokról szóló törvény 7 . \$-ában szereplő „cselekmény” (action) kifejezés magában foglalja-e egy már megkezdett projekt befejezését. ${ }^{42} \mathrm{E}$ passzus ugyanis tiltotta azokat a cselekményeket, amelyek a törvény mellékletében szereplő fajok fennmaradását veszélyeztetik. ${ }^{43} \mathrm{~A}$ Legfelsőbb Bíróság döntéshozatalakor a vita nem a projekt folytatásáról, hanem a befejezéséről szólt. A projekt valójában $80-85 \%$-ban elkészült, teljes befejezéséhez csupán a zsilipek lezárása és néhány kisebb műtárgy (például gyaloghíd) megépítése hiányzott. A bíróság döntése szerint a kérdéses action szó mindennemü cselekményt magában foglal függetlenül attól, hogy az projektlezáró cselekmény-e, vagy sem. ${ }^{44}$ Mit kezdhetünk ezzel a meglehetősen pikáns üggyel?

A jogállítók legfőbb vétke a hiú dicsőségvágy. Mi más hajthat egy biológust, hogy csekély tudományos értékkel bíró, sziszifuszi tevékenységre pazarolja az idejét, és a különféle, egymástól alig elkülöníthető sügérek elkülönülő fajait azonosítsa? És mi más hajthat egy jogászprofesszort és egy joghallgatót, hogy megakadályozzon egy, az adófizetők pénzének dollármillióiból épülő projektet, amely egy egész régió életszínvonalát lenne képes megváltoztatni? Tettük erényes olvasata pedig az erősség, hiszen egy magát megvédeni képtelen, jelentéktelen kis faj megsegítésére szövetkez-

40 Harold H. Bruff: Legislative Formality, Administrative Rationality. Texas Law Review, 63. (1984), 2. 207-250. 224.

41 Egyesek szerint ezzel szemben a sügérfaj értéke felbecsülhetetlen, ld. Edwin M. Smith: The Endangered Species Act and Biological Conservation. Southern California Law Review, 57. (1984), 361-413. 389.

42 Az esetről ld. Ronald Dworkin: Law's Empire. Cambridge, Harvard University Press, 1986, 23. Erről pedig Steven J. Burton: Ronald Dworkin and Legal Positivism. Iowa Law Review, 73. (1987), 109-129. 122.

43 George C. Coggins: Protecting the Wildlife Resources of National Parks from External Threats. Land and Water Law Review, 22. (1987), 1. 1-28. 9.

44 Zygmunt J. B. Plater: Statutory Violations and Equitable Discretion. California Law Review, 70. (1982), 3. 524-594. 586. 
tek. Fellépésük igen nagy felháborodást keltett, a vétek pedig kicsit súlyosabb, mint amilyen erényes az erény. A panasz normatív ereje így inkább a gyengébb szankciók alkalmazását sugallja.

Ami az érintett normát, a veszélyeztetett fajokról szóló törvényt illeti, a mögöttes jogalkotói szándékot mindenképp pozitívnak kell értékelnünk. A konkrét esetben a legjobb erkölcsi olvasata azonban bajosan lehet az, hogy megakadályozza a nagyszabású projekt bevezetését. Emiatt a norma normatív ereje kicsi, és az enyhébb szankciók irányába mutat. A kettő összevetéséből a kérelem elutasítása következik, ami ismét a bíróságéval ellentétes eredményt jelent. (Lásd a 7. ábrát. A panasz vektora enyhén felfelé mutat, és elég hosszú. A norma vektora lefelé áll, és rövid, összegük elutasítást jelez.)

\author{
Megsemmisítés \\ Mulasztás \\ Alk. követelmény
}

Elutasítás

7. ábra: A Tennessee Valley Authority v. Hill ügy

Forrás: a szerző szerkesztése

\section{5. Összegzés}

A fenti néhány példából talán kiderült, hogy a lelkiismeret-alapú elemzés ugyanolyan mély vizsgálatot tesz lehetővé, mint a hagyományos dogmatikai. Csupán más fogalmakkal, értékekkel és korlátokkal dolgozik. A lelkiismereti konstitucionalizmusnak azonban egy komoly előnye biztosan van a klasszikus analízissel szemben: egy sokkal közérthetőbb, fontosabb, mindenkit érintő területet problematizál és tesz közüggyé, mégpedig a bünök és az erények világát.

Amikor a fenti módszerrel dolgozunk, nem a bíróktól megszokott mérlegelést végezzük, és nem az a legfőbb elvárásunk, hogy indokolásunk következetes és koherens legyen. Inkább egyfajta meditációt végzünk, ahol a tárgybeli cselekményt mintegy interiorizálva a saját bűnös és erényes késztetéseinkre figyelünk. Legfőbb elvárásunk pedig az, hogy ne engedjük elnyomni magunkban azt a tiszta hangot, amely az adott cselekmény őszinte megítéléséhez szükséges.

Ne ijedjen meg a figyelmével eddig e sorokat megtisztelő olvasó! Nem vesztettem el a józan eszem: nem hiszem, hogy a fenti séma valaha kiszoríthatja a bevett módszereket. Mindez annak ellenére igaz, hogy sokkal ősibb hagyományokra támaszkodik, mint a jogi okfejtések. Viszont talán a keresztény embereknek vagy olyanoknak, 
akik a saját belső igazságérzetükre támaszkodva próbálnak meg orientálódni az egyre keszekuszábbá váló világban, hasznos lehet a fenti módszer. A lefolytatott „lelkiismeret-vizsgálatok" nemcsak egy megalapozott véleményhez segíthetnek hozzá egy-egy társadalmilag fontos jogvita megítélése kapcsán, hanem jó gyakorlatul szolgálhatnak arra is, hogy egy-egy ügyet az igen-igen, nem-nem perspektívájából tudjunk megítélni. Aki pedig megizmosodik ebben a műveletben, az nem csupán okosabb lesz, hanem közelebb kerül a jog legfőbb elöírásának, a honeste viverének, a tisztességes életre szólító parancsnak a teljesítéséhez.

\section{Irodalomjegyzék}

A katolikus Egyház katekizmusa. Ford. Dr. Pápai Lajos, Dr. Gál Ferenc, Dr. Török József. Budapest, Szent István Társulat, 1994.

Arkes, Hadley: The Natural Law Challenge. Harvard Journal of Law \& Public Policy, 36. (2013), 3. 961-975.

Ashley, Kevin D.: Teaching Law and Digital Age Legal Practice with an AI and Law Seminar. Chicago-Kent Law Review, 88. (2013), 3. 783-844.

Beehler, Rodger: Legal Positivism, Social Rules, and Riggs v. Palmer. Law and Philosophy, 9(3). (1990), 285-293. DOI: https://doi.org/10.1007/BF01406532

Black, Bert: A Unified Theory of Scientific Evidence. Fordham Law Review, 56. (1988), 4. 597-695.

Bruff, Harold H.: Legislative Formality, Administrative Rationality. Texas Law Review, 63. (1984), 2. 207-250.

Burton, Steven J.: Ronald Dworkin and Legal Positivism. Iowa Law Review, 73. (1987), 109-129.

Cardozo, Benjamin N.: The Nature of the Judicial Process. Journal of Law: A Periodical Laboratory of Legal Scholarship, 1. (2011), 2. 329-348.

Carrio, Genaro R.: Professor Dworkin's Views on Legal Positivism. Indiana Law Journal, 55. (1979), 2. 223.

Cassianus, Johannes: Az egyiptomi szerzetesek tanítása. I. rész. Pannonhalma-Tihany, Magyar Bencés Kongregáció, 1998.

Coggins, George C.: Protecting the Wildlife Resources of National Parks From External Threats. Land and Water Law Review, 22. (1987), 1. 1-28.

Dworkin, Ronald: Law's empire. Cambridge, Harvard University Press, 1986.

Dworkin, Ronald: Seven Critics. Georgia Law Review, 11. (1977), 1201-1268.

Evagriosz, Pontikosz: A szerzetes. Pannonhalma, Pannonhalmi Főapátság Bencés Kiadó, 2018.

Gellius, Aulus: Attikai éjszakák. Budapest, Európa, 1968.

Giles, Stephen G.: Mandatory Liability Insurance for Firearm Owners: Design Choices and Second Amendment Limits. Engage, 14. (2013), 1. 18-24.

Hancock, Stewart F., Jr.: Meeting the Needs: Fairness, Morality, Creativity and Common Sense. Albany Law Review, 68. (2004), 1. 81-104.

Jhering, Rudolf von: Kampf ums Recht. Bécs, Manz, 1894.

Kopel, David B.: The Natural Right of Self-Defense: Heller's Lesson for the World. Syracuse Law Review, 59. (2008), 30. 999-1016.

Mensching, Günther: Moderne Elemente der Staatsauffassung des Thomas von Aquin. In Schönberger, Rolf (szerk.): Die Bestimmung des Menschen und die Bedeutung des Staates. BadenBaden, Nomos, 2017. DOI: https://doi.org/10.5771/9783845251103-227 
Meyer, William B.: The Background to Riggs v. Palmer. American Journal of Legal History, 60. (2020), 1. 48-75. DOI: https://doi.org/10.1093/ajlh/njz027

Moyn, Samuel: Christian Human Rights. Philadelphia, University of Pennsylvania Press, 2015.

O'Hagan, Cindy J.: When Seeing is not Believing: The Case for Eyewitness Expert Testimony. Georgetown Law Journal, 81. (1993), 3. 741-772.

Pius, XI., pápa: Divini redemptoris. Elérhető: http://szit.katolikus.hu/feltoltes/Divini\%20Redemptoris.pdf (A letöltés dátuma: 2020. 09. 24.)

Plater, Zygmunt J. B.: Statutory Violations and Equitable Discretion. California Law Review, 70. (1982), 3. 524-594. DOI: https://doi.org/10.2307/3480213

Risinger, Michael - Loop, Jeffrey L.: Three Card Monte, Monty Hall, Modus Operandi and "Offender Profiling": Some lessons of Modern Cognitive Science for the Law of Evidence. Cardozo Law Review, 24. (2002), 1. 193-286.

Seneca, Lucius A.: De ira. A haragról. Budapest, General, 2001.

Shapiro, Robert E.: Natural Rights: Requiescant in Pace. Litigation, 39. (2013), 3. 55-58.

Smith, Edwin M.: The Endangered Species Act and Biological Conservation. Southern California Law Review, 57. (1984), 361-413.

Spitzer, Robert J.: Gun Law, Policy, and Politics. New York State Bar Association Journal, 84. (2012), 6. 35-42.

Szent Ignác, Loyolai: Lelkigyakorlatok. Budapest, Jezsuita, 2019.

Twining, William: The New Evidence Scholarship. Cardozo Law Review, 13. (1991), 2-3. 295-302. 